\title{
413. 重粒子線治療における固定具使用の諸問題について
}

STUDY OF PATIENT IMMOBILIZATION SYSTEN FOR CARBON BEAN THERAPY

放射線医学総合研究所 重粒子治寮センター

砂岡正良鶴岡伊知郎 渡辺秀雄 石居隆義 田尻稳 黒岩俊隆 双下邦雄

【はじめに】

重粒子線治療はその線量分布特性から従来のPHOTONを使用した治療に比へてより大量 の線量集中が期待できる。しかし、集光照射などにも共通するようにTARGETに対する 線量が集中するほど治療の精度が要求されることも事実である。

【目的】

重粒子線治療を行う場合においては全症例について固定具を使用しているが成型後の 変化が大きいためセットアップの精度に問題を抱えている。現在治療患者固定用のシ エル材には多くの種類のものが出回っているがメッシュタイプのものが作成後の樎小 比較的少なく患者の感触も良好のようである。しかしながらメッシュタイプでは穴の あいている部分とそうでない部分ではビームのレンジに差が生じることが予湘される ためもその変化に関して検討する。

【方法】

通常の手順に従って頭部ランドファントームを使用し、シェルを作成する。作成した シェルの一部を切り取りフィルム法にて290 MeV CARBON BEAMの抗大ブラッグピーク

(以下SOBP 60 とする) を测定する。また、この測定で予想されるレンジの変化は 1 $2 \mathrm{~mm}$ 程度であるため種々のビームライン機器によるレンジ変化のプロファイルが明確 に测定することが困難であると予测されるため、作成前のシェルを皘層しレンジの変 化量を增加した状態で散乱体、レンジシフタなどによる影整を測定する。

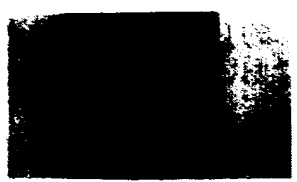

Fig 1

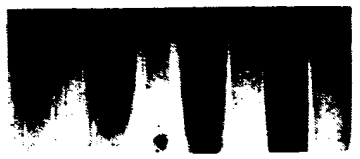

Fig 2

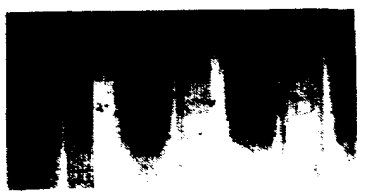

Fig 3

\section{【結果】}

通常の手順により作成したシェルによるレンジの変化は $1.5 \mathrm{~mm}$ であり (Fig1)、使用したシェルの厚さとほほ一致した。シェルの組成、密度 についてはメーカーがテータを公表していないため不明だが結果とし てシェルを通過した距離の分だけレンジがビーム上流側にシフトして いるものと考えられる。積層したシェルを使用した実験では、散乱体 やレンジシフタ等ビームライン機器による影響はほとんどみられず、 むしろ媒質中の通遇距離による影警が顥著であった(Fig2〜Fig5)。

\section{【考察】}

$1.5 \mathrm{~mm}$ のレンジの変化は治療範囲の上流（加速器）側及び下流側で計 画した治療範囲に比べて凹凹のレンジとなるが、この值に関しては治療部 位によってマージンの取り方が異なることもあり検討が必要である。 また、欧米ではメッシュタイプのシェルを使用して柆子線治療を行って いる施設むあり、治療計画時にシェルの凹凸をデータに取り込んで計画 するためボーラスによって補正がかかり、治療には問題がないとする考 えも存在し、今後の検討課題としたい。

種々のビームライン機器による凹凸のプロファイルへの影辢については、 レンジによるプロファイルの変化もさることながら 2 ビームの影整もみ られ、今後のなおいっそうの検討が必要であると考える。

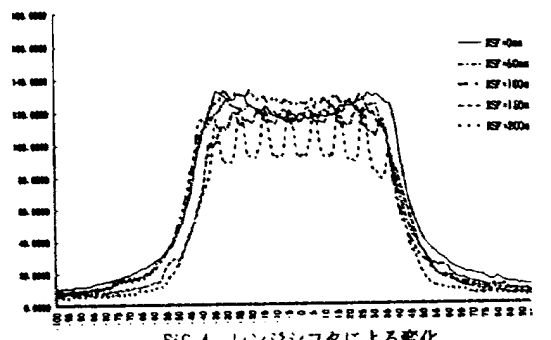

FiG 4.レンシシフタによろ花化

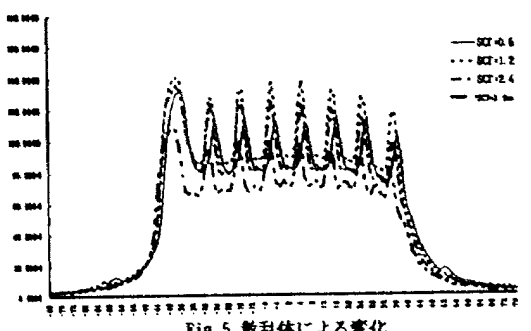

